\title{
Jesus van Nasaret se bevrydende visie vir'n geweldadige samelewing
}

S J Joubert

\author{
ABSTRACT
}

Jesus of Nazareth's liberating vision for a violent society

All political, economical and religious power in first century Palestine were in the hands of less than 5\% of the population. This gave rise to a situation of "social rootlessness" among and different violent responses from many Jewish peasants. Within this society, characterized by "ideological" and physical violence, Jesus of Nazareth proclaimed an encompassing new reality, the Kingdom of God. In this regard He not only offered salvation to the victims of violence, but also expected a new, violent-free, orientation and code of conduct towards God and all human beings from his followers.

1

\section{INLEIDING}

Die Suid-Afrikaanse samelewing is tans een van die geweldadigste samelewings ter wêreld ${ }^{1}$. Volgens onlangse berigte in die media word daar byvoorbeeld meer moorde binne die bestek van twintig dae binne die groter Johannesburgarea gepleeg as in die ganse Brittanje in ' $n$ jaar. Hierdie skrikwekkende toedrag van sake het nie alleen 'n verlammende effek op die land se ekonomie nie, maar ook op die gemeenskapslewe en menswees van alle inwoners van die land.

Te midde van die pogings van politici en gemeenskapsleiers om die bose spiraal van geweld in Suid Afrika te probeer deurbreek, het die kerk ook 'n uiters belangrike rol te speel om mense weer met God en met mekaar in verbinding te bring. Om dit egter na behore te kan doen, moet gelowiges nie alleen op hoogte wees met die komplekse problematiek van die Suid-Afrikaanse samelewing in die breë nie, maar ook met die norme wat die Bybel ten opsigte van gelowiges se roeping en taak in hierdie verband bied. Laasgenoemde aspekte vra veral nou ons aandag in hierdie artikel.

Vanweë die omvattendheid en veelkantigheid van die Bybelse uitsprake oor geweld, konsentreer ons slegs op Jesus van Nasaret se optrede en leringe wat met hierdie problematiese aangeleentheid verband hou, soos wat dit in die sinoptiese evangelies aan die orde gestel word. Die fokus val hier op die nuwe werklikheid ("die koninkryk van God") wat Jesus aangekondig het binne die gewelddadige samelewing van sy dag. Ten einde Jesus se woorde en dade wat met geweld verband hou na behore te verstaan, word'n kort omskrywing van die term 
"geweld" eerstens aangebied, waarna in breë trekke by die heersende sosiohistoriese omstandighede en die verskillende manifestasies van geweld in Palestina in die eerste eeu $\mathrm{nC}$ stilgestaan word ${ }^{2}$.

Te midde van vele omskrywings van die term "geweld", verstaan ons hieronder: (a) die aanwending van doelbewuste fisieke mag jeens iemand. Dit word onregmatig gebruik wanneer persone opsetlik liggaamlik beseer of selfs gedood word; (b) die gebruik van mag in metaforiese verband waar iemand se persoon en naam benadeel word deur onder andere die daarstelling van strukture en instellings wat hulle menswaardigheid misken, die inhibering van mense se denke deur die "kanonisering" van bepaalde ideologieë, asook deur beledigings en etikettering van andere.

\section{DIE HEERSENDE SOSIALE OPSET IN PALESTINA RONDOM DIE EERSTE EEU NA CHRISTUS}

\subsection{Die Romeinse politieke beheer oor Palestina}

Op staatkundige gebied het die politieke mag in Palestina in Jesus se tyd in die hande van Rome gelê. Sedert $63 \mathrm{vC}$, met Pompeius se besetting van Jerusalem, het die Romeine indirek (deur middel van Herodes die Grote en sy seuns) en regstreeks (deur middel van prokurators) oor die verskillende streke van Palestina regeer. Alhoewel hulle aan die Jode 'n vry hand gegee het wat die organisering van hulle godsdiensbeoefening betref, het hulle tog deurentyd swaar finansiële verpligtinge op die Joodse bevolking se skouers geplaas. Bo en behalwe die jaarlikse godsdienstige bydraes wat laasgenoemdes aan die tempel moes gee, moes hulle ook nog swaar belastings aan die Romeine oorbetaal. Trouens, dit word bereken dat die gemiddelde Joodse boer rondom die eerste eeu meer as $40 \%$ van sy totale jaarlikse produksie op dié wyse moes afstaan. Hiermee saam het vele Romeinse prokurators baie onsimpatiek jeens Joodse godsdienstige gebruike gestaan en dit het vir hulle die gramskap van die grootste deel van die Joodse bevolking op die hals gehaal. Veral Pontius Pilatus (26-36 $\mathrm{nC}$ ) het hom aan heelwat wreedhede teenoor die Jode skuldig gemaak ${ }^{3}$. Rondom die middel van die eerste eeu $\mathrm{nC}$ het die konfrontasies tussen die Romeinse besetters en die Jode sodanig toegeneem dat dit uitgeloop het op die Joodse rewolusie ( $66 \mathrm{nC}$ ) en die Romeinse besetting van Jerusalem $(70 \mathrm{nC}$ ).

3.2 Die Joodse godsdienstige elite se kategorisering van die werklikheid

Die hoëpriester en die Joodse Raad in Jerusalem het die meeste mag onder die 
Jode rondom die eerste eeu besit. Hulle het oor die bevoegdheid beskik om die voorskrifte en reëls neer te lê waarvolgens God gedien moes word. Hiermee saam het hulle ook bepaal welke finansiële bydraes die Jode jaarliks aan die tempel moes oorbetaal. Heelwat Fariseërs en Sadduseërs was ook in diens van, of in noue kontak met die Joodse Raad en die priesterlike aristokrasie in Jerusalem en het daartoe bygedra om die invloed van die tempel orals in Palestina te help vestig.

Vanweë die hoëpriesterlike- en priesterlike families se groot mag het hulle, saam met ander invloedryke groepe soos die afstammelinge van Herodes die Grote, die grondbaronne, die Sadduseërs, en natuurlik ook die Romeinse owerhede, algehele beheer oor die Palestynse ekonomie gehad. Minder as 5\% van die bevolking het egter tot hierdie groepering behoort. Hulle was hoofsaaklik in die stede woonagtig en het dit uitsluitlik rondom die bevordering van hulle eie belange ingerig sodat daar nie werklik sprake van goedgeordende ekonomiese infrastrukture in die eerste eeuse Palestina was nie ${ }^{4}$.

Alhoewel dit moeilik is om 'n presiese beeld van die Joodse leiers se godsdienstige opvattinge gedurende die eerste eeu te vorm, blyk dit uit die beskikbare inligting dat hulle vaste idees gehad het oor hoe God gedien moes word en hoedanig sy wet in die praktyk gehoorsaam moes word. Te midde van die onderlinge verskilpunte rondom die verstaan van die wet van Moses, was hulle wel met mekaar eens dat die ganse werklikheid in kategorieë van heilig/onheilig, of rein/onrein, ingedeel moes word ${ }^{5}$. Uit die Joodse geskrifte vanuit die tweede en derde eeu nC kry ons 'n goeie profiel van veral die Fariseërs se mensbeskouing in dié verband. Hiervolgens was daar onder andere heilige mense (Jode en bekeerdes tot die Jodedom) en onheilige mense (heidene en sondaars). Binne die kategorie van "heilige mense" het daar weer verskillende grade van heiligheid bestaan, soos wat die Misjna-traktaat, Kelim, aantoon. Hiervolgens is Israeliete hiërargies soos volg ingedeel: (i) priesters; (ii) leviete; (iii) gewone Israeliete; (iv) bekeerdes tot die Judaisme; (v) vrygemaakte slawe; (vi) priesters wat uit hul ampte onthef is; (vii) tempelslawe; (viii) kinders wat uit "verbode" huwelike gebore is, en (ix) ontmandes. Heiligheid is ten nouste aan mense se betrokkenheid by die tempel en die amptelike godsdiens van die Jode gekoppel. Mense met ernstige liggaamsgebreke, asook diegene wat vanweë sekere siektes nie toegelaat is om aan die tempeldiens deel te neem nie, is as kulties onrein beskou. Dit is egter veral die heidene wat as besonder onrein beskou is. Huwelike met hulle is verbied en kontak met hulle is deurgaans ontmoedig.

Die godsdienstige leiers het ook duidelike reëls neergelê ten opsigte van die tipe beroepe wat Jode kon volg en watter beroepe hulle moes vermy ${ }^{6}$. Binne laasgenoemde kategorie het beroepe soos skaapwagters, winkeleienaars, tollenaars, dobbelaars en skrywers en verspreiders van ketterse geskrifte geressorteer. Hierdie mense is as kulties onrein beskou en daar is beledigend na hulle verwys as "die 
mense van die land" (die הצר nie en wat ook nie die Sabbatsgebooie streng genoeg onderhou het nie, is ook in hierdie kategorie geplaas.

Van die Joodse bevolking is verwag om by bogenoemde en ander soortgelyke skematiserings van die werklikheid in te val en om hul lewens dienooreenkomstig in te rig. Diegene wat dit nie gedoen het nie, is deur die Joodse godsdienstige leiers met minagting bejeën. Hulle is onder andere nie toegelaat om aan amptelike godsdienstige bedrywighede deel te neem nie en is geëtiketteer as "sondaars" en as "die mense van die land".

\subsection{Sosiale ontworteldheid binne die Joodse samelewing}

Die grootste gedeelte van die Joodse bevolking was kleinboere en dagloners. Gedurende die eerste eeu $\mathrm{nC}$ moes hulle deurentyd worstel om kop bo water te hou. Swak ekonomiese infrastrukture, droogtes, uitbuiting deur die elite, swaar belastings wat aan die Romeine oorbetaal moes word, godsdienstige bydraes aan die tempel, ensovoorts, het 'n swaar skuldlas op hulle geplaas wat tot gevolg gehad het dat baie van hulle onder die broodlyn geleef het. Vanweë hierdie uiters ongunstige ekonomiese omstandighede het groot groepe Jode in dié tyd hulle aardse besittings verloor, en is sommige van hulle selfs as slawe verkoop?

Die meeste Joodse families het aan die lewe probeer bly deur die landbouprodukte wat hulle verbou het op die dorpsmarkte vir ander lewensmiddele te verruil. Handelaars, boere, dagloners en vakmanne het ook na die groter stede gestroom en het hier met mekaar gewedywer om hulle middele en produkte aan diegene te verkwansel wat wel in staat was om dit te kon koop. Hierdie persone het hulle veral aan die buitewyke van die stede gevestig tussen ander noodlydendes en sosiaal uitgeworpenes, soos bedelaars en siekes, wat van aalmoese afhanklik was om aan die lewe te bly.

Vanweë die haglike ekonomiese omstandighede en onstabiele politieke situasie wat deur die Romeinse besetting te weeg gebring is, het baie Jode, bo en behalwe die verlies van hulle aardse besittings, ook nog hul eerbare name binne die samelewing verloor omdat hulle hulle moes wend tot onaanvaarbare beroepe soos skaapwagters en tollenaars, asook tot oneervolle praktyke soos bedelary en misdaad. Dit het aanleiding tot 'n toestand van "sosiale ontworteldheid" onder baie Jode gegee.

Op 'n hoë vlak van veralgemening sou ons kon sê dat Palestina gedurende die eerste eeu veral in twee groepe verdeel was, naamlik aan die een kant die elite wat oor al die politieke en ekonomiese mag beskik het, en aan die ander kant die oorwegend agrariese bevolking, woonagtig in klein dorpies en op die platteland, wat 'n bestaansekonomie gehandhaaf het en groot armoede beleef het. Eersgenoemde 
groepering het op godsdienstige gebied die leidende rol gespeel deur die reëls te bepaal waarvolgens God gedien moes word.

Vele Jode was rondom die eerste eeu nC slagoffers van geweld. Bo en behalwe die fisieke geweld van die kant van die Romeinse besetters, was hulle ook nog uitgelewer aan die "ideologiese" geweld van die godsdienstige leiers wat hulle eie beskouinge op die res van die bevolking afgedwing het en diegene verwerp het wat nie by hulle skematisering van die werklikheid ingeval het nie.

\section{4}

GEWELDADIGE PROTES IN PALESTINA RONDOM DIE EERSTE EEU

As gevolg van die haglike ekonomiese omstandighede en geweldadige uitbuiting deur die elite en die magshebbers waaraan vele Jode in die eerste eeu blootgestel was, het sommiges by sogenaamde radikaal teokratiese groepe aangesluit om op een of ander manier hul verlore status te probeer terugwen. Hierdie teokratiese groepe was protesbewegings teen die heersende omstandighede in Palestina en het hulle dikwels tot geweldadige optredes teen die Romeine gewend. Op dié manier wou hulle God se heerskappy oor die grondgebied van Israel sigbaar laat realiseer. Sommige van die leiers van hierdie groepe het hulleself dan ook as Messiaanse figure beskou wat gemeen het dat hulle 'n leidende rol met die aanbreek van God se ryk sou speel.

In $6 \mathrm{nC}$ het 'n groep Jode onder leiding van Judas die Galileër in opstand gekom toe die Romeine 'n sensusopname onder die Jode wou hou. Hy het sy volgelinge tot geweldadige verset teen Rome aangehits en hulle verbied om enige belasting aan die Romeine te betaal. Hierdie opstand is egter vinnig deur die Romeine oncierdruk. Rondom die jaar $35 \mathrm{nC}$ het 'n onbekende Samaritaanse figur op die toneel verskyn wat aangekondig het dat sekere heilige voorwerpe deur Moses op die heilige berg van die Samaritane, Gerisim, begrawe is. Saam met 'n groot groep gewapende volgelinge het hy na Gerisim opgetrek om hierdie voorwerpe op te grawe, want na hulle oordeel sou die eindtyd met die vind hiervan aanbreek en die Romeine se mag oor hulle beëindig word. Pilatus het hulle egter voorgekeer en baie van hulle laat doodmaak.

In die tyd na Jesus se aardse optrede het nog 'n aantal persone op die toneel verskyn wat ook gepoog het om die Romeine op een of ander wyse in Palestina te onttroon, soos Teudas (44-46 nC) en 'n Jood uit Egipte (55 nC). Dit was egter veral die sestigerjare wat van die ontstuimigste tye in Palestina gedurende die eerste eeu was. Teen hierdie tyd het die vlam van haat teen die Romeine baie hoog onder die Jode gebrand. 'n Georganiseerde stedelike terroristebeweging, bekend as die Selote, was in dié tyd baie aktief en het 'n aantal lede van die Joodse aristokrasie vermoor wat met die Romeine kontak gehad het. As gevolg van hulle 
geweldadige verset het 'n volskaalse rewolusie teen Rome rondom $66 \mathrm{nC}$ uitgebreek wat tot gevolg gehad het dat 'n Romeinse leër Jerusalem beset het en die tempel in $70 \mathrm{nC}$ met die grond gelyk gemaak het.

\subsection{Die evangelies as ons vernaamste bronne oor Jesus se optrede}

Ons vernaamste bronne oor die lewe en optrede van Jesus van Nasaret is die sinoptiese evangelies en Johannes. Hierdie geskrifte is egter nie biografieë oor sy lewe nie, maar gemterpreteerde vertellinge oor bepaalde fasette van sy openbare optrede. Hierdie vertellinge het ook nie in 'n lugleegte ontstaan nie. Dit is oorspronklik aan spesifieke vroeg-Christelike gemeenskappe gerig ten einde hulle te begelei om hulle lewens aan die hand van Jesus se woorde en dade in te rig. Die evangelieskrywers het met ander woorde hulle evangelies op skrif gestel om telkens bepaalde boodskappe oor Jesus se optrede aan hul beoogde lesers oor te dra ten einde geloof by laasgenoemdes te wek en/of te versterk. Sodoende het ons in hierdie geskrifte met verskillende (wedersyds aanvullende) perspektiewe op Jesus se optrede te make. Ons moet dus nie verwag om een of ander objektiewe, interpretasievrye beeld van Jesus hierin aan te tref nie. Elke evangelieskrywer het sy verhaal oor Jesus vanuit sy eie situasie en die spesifieke probleme wat hy wou aanspreek, neergepen. So plaas Markus byvoorbeeld veral klem op Jesus wat die Seun van God is, terwyl Matteus weer nadruk op Jesus as die beloofde Messias van Israel lê en Lukas op sy beurt die fokus op Jesus as die Verlosser van die hele wêreld laat val. Die Johannesevangelie loop sy eie pad as 'n komplekse teologiese interpretasie oor Jesus se aardse optrede, sodat ons nie hier in besonderhede by dié boek se boodskap kan stilstaan nie.

Sonder om verstrik te raak in die problematiek rondom die verskillende maniere waarop die evangelieskrywers hulle onderskeie verhale oor Jesus van Nasaret geïnterpreteer het, aanvaar ons vir die doeleindes van hierdie artikel dat hulle weergawes van sy woorde en dade korrespondeer met die wyses waarop Jesus Homself tydens sy openbare optrede bekendgemaak het. Aan die hand van die gegewens in die sinoptiese evangelies gaan ons vervolgens ' $n$ profiel konstrueer van Jesus se verkondiging van 'n nuwe werklikheid wat verband hou met mense se optrede teenoor mekaar. Prakties behels dit die versameling en interpretasie van (wedersyds oorvleuelende) informasie vanuit dié evangelies wat met ons vraagstelling verband hou. Wanneer nodig, sal aanduidings ook verskaf word van die maniere waarop die onderskeie evangeliste hulle stof weergegee en verstaan het. Uiteraard moet ons onthou dat dié konstruksie tentatief van aard is omdat ons nie oor al die stukke van die legkaart rakende Jesus se openbare optrede beskik nie. 
Boonop werk ons ook met bronne wat reeds vanuit bepaalde invalshoeke na sy optrede kyk, en wat ons op ons beurt ook weer vanuit ons eie vraagstellings analiseer.

\subsection{Jesus bring 'n nuwe realiteit vir die slagoffers van geweld}

Vir die meeste Jode van Jesus se dag was dit 'n uitgemaakte saak dat God hulle koning was. Hy het dit immers sigbaar aan hulle gedemonstreer deur aan hulle 'n grondgebied te gee waarop hulle kon woon, soos wat Hy aan die aartsvaders beloof het. En in Jerusalem, die heiligste plek op aarde, het God se tempel gestaan as teken van sy teenwoordigheid. Hiermee saam het Joodse mans ook nog die teken van die besnydenis gedra as bewys dat hulle aan God behoort het.

Binne hierdie godsdienstige milieu het Jesus egter kom sê en wys dat die koninkryk van God op 'n dinamiese manier met sy eie optrede aangebreek het ${ }^{8}$. Hyself was die gesaghebbende aankondiger en brenger van hierdie koninkryk, soos wat sy genesings en duiweluitdrywings onder andere sigbaar geillustreer het (vgl Matt 11:2-6; 12:22-32). En in sy gelykenisse het Jesus, aan die hand van bekende voorbeelde uit sy alledaagse wêreld, sy omstanders geleer hoedanig hierdie koninkryk moet wees (vgl bv Matt 13; Mark 4). Jesus se radikale verkondiging van 'n nuwe werklikheid te midde van die ander religieuse werklikhede van sy dag het Hom die gramskap van veral die Joodse leiers op die hals gehaal omdat dit nie met hulle eie kategoriserings van mense geklop het nie. Kom ons kyk kortliks na 'n paar fasette in hierdie verband:

\subsubsection{God se koninkryk is bedoel vir sondaars en uitgeworpenes}

Volgens Markus het Jesus gese dat Hy nie gekom het om mense te roep wat op die regte pad is nie, maar wel sondaars (2:17). En soos wat ons vroeër reeds gesien het, was sondaars veral diegene wat volgens die Joodse godsdienstige leiers God se gebooie verontagsaam het, en/of nie in staat was om hul lewens nougeset volgens al die religieuse wette van hulle dag in te rig nie. Hulle is as onrein beskou en kon as gevolg hiervan nie aan amptelike godsdienstige aktiwiteite deelneem nie. "Godvresende" Jode is ook nie toegelaat om met hulle te meng nie ten einde nie deur hulle verontreinig te word nie. "Sondaars" was sodoende die slagoffers van die "ideologiese" geweld van die godsdienstige elite.

Jesus het tydens sy openbare optrede egter gereeld kontak met diegene gemaak wat in bogenoemde kategorie geval het, insluitend prostitute en tollenaars. Laasgenoemdes was veral 'n veragte groep mense vanweë hul grootskaalse uitbuiting van persone by die verskillende tolpunte in Palestina. Baie van die godsdienstige leiers was van mening dat tollenaars buite die dampkring van God se 
genade gestaan het. Jesus het egter gereeld saam met sommige van hulle geëet (bv Mark 2:13-14), terwyl hulle en ander sondaars ook dikwels na Hom kom luister het (Luk 15:1).

Jesus se kontak met tollenaars het groot opslae onder die mense van sy dag gemaak. Volgens die sinoptiese evangelies was die godsdienstige elite veral ontsteld oor die feit dat Hy Hom met hulle en ander "onrein" persone opgehou het (vgl bv Luk 7:36-50;15:2;19:7). Volgens Matteus het Jesus by geleentheid dan ook een van die "etikette" wat hulle in dié verband aan Hom toegevoeg het, aangehaal: "Die Seun van die mens het gekom en geëet en gedrink, en hulle sê: 'Kyk daar, 'n vraat en 'n wynsuiper, 'n vriend van tollenaars en sondaars"' (11:19).

Bo en behalwe hierdie mense het Jesus volgens die sinoptiese evangelies ook uitgereik na diegene wat nie eervolle posisies binne die hiërargiese samelewingstrukture van sy dag beklee het nie, soos vroue, heidene en kinders (bv Mat 7:11-12; Mark 9:33-36). Voorts het Jesus ook kontak gemaak met persone wat hulle eervolle posisies binne die samelewing verloor het vanweë armoede en siekte. Aan diesulkes het Hy die koninkryk van God op 'n heel konkrete wyse kom aanbied, soos wat sy genesings en sy gelykenisse onder andere illustreer. Jesus het volgens die evangelieskrywers ook benadruk dat die rolle binne God se koninkryk omgeruil het: hierbinne is die armes, uitgeworpenes en sondaars nou diegene oor wie God Hom ontferm omdat hulle al hulle vertroue op Hom stel, terwyl die maghebbers en die rykes uitgesluit word vanweë hulle vertroue op aardse besittings en politieke mag.

In teenstelling met die godsdienstige leiers met hul streng indelings van die werklikheid in terme van heilige en onheilige kategorieë, blyk dit uit die sinoptiese evangelies dat Jesus nie alleen net vir God op 'n nuwe wyse aan die mense van sy dag kom bekendgestel het nie, maar dat Hy ook nuwe riglyne vir toegang tot sy koninkryk neergelê het. Veral aan diegene wat as sondaars en uitgeworpenes beskou is en wat die slagoffers van die ideologiese geweld van die magshebbers was, het Jesus naamlik kom wys dat God hulle onvoorwaardelik aanvaar as hulle positief op sy prediking sou reageer.

5.3 'n Nuwe werklikheid met 'n nuwe waardesisteem waar die gebruik van geweld taboe is

\subsection{1 'n Nuwe gedragskode vir navolgers van Jesus teenoor andere}

Jesus het nie alleen net 'n nuwe weg na die hart van God verkondig en bemiddel nie, maar ook duidelike riglyne neergelê waarvolgens sy nuwe navolgers teenoor andere moes optree. Ten opsigte van laasgenoemde aspekte kan ons nie anders as om veral by Matteus, die groot "onderwysende evangelie", stil te staan nie. Hier in 
die alombekende bergrede (Mat 5-7), waar Matteus vir Jesus voorhou as die gesagvolle "wetgewer" van die koninkryk van God, word radikale beginsels oor naasteliefde vir al die onderdane van sy koninkryk necrgelêt". In die bergrede gaan dit deurgaans oor mense wat reeds God se genade aanvaar het; oor wie se lewens die "saligsprekinge" (5:3-12) uitgespreek is. Dit is aan diegene dat Jesus nou kom sê: "alles wat julle wil hê dat die mense aan julle moet doen, moet julle ook aan hulle doen" (7:12). Hierdie goue reël dien volgens Hom as dié norm waarvolgens hulle onder alle omstandighede teenoor andere moet optree. In die sogenaamde antiteses in die bergrede (5:21-48) stippel Jesus volgens Matteus 'n klompie praktiese implikasies rakende dié norm uit. Teenoor die godsdienstige leiers se interpretasies van die wet (wat telkens ingelei word met woorde soos: "Julle het gehoor dat daar gesê is"), kom stel Jesus sy eie radikale interpretasies daarvan as nuwe norm vir sy volgelinge (wat weer ingelei word met die woorde: "Maar Ek sê vir julle"). So het die Fariseërs byvoorbeeld gesê dat moord (dit wil sê, die fisiese neem van iemand se lewe) nie toelaatbaar is nie. Hierteenoor stel Jesus dat moord eintlik al klaar plaasgevind het waar iemand anders as 'n gek of 'n idioot uitgeskel is (5:21-22).

Jesus bied volgens Matteus 'n heeltemal ander perspektief op die lewe as die godsdienstige leiers van die Jode. Lewe in sy totaliteit is vir Hom 'n gawe uit God se hand. Deur andere te beledig en hulle goeie naam in die gedrang te bring, neem jy iets uit hulle lewens weg; perk jy hulle menswees drasties in. Daarom verwag Jesus van sy navolgers om ander mense se lewens in totaliteit te respekteer en hulle nie aan enige vorm van ideologiese geweld skuldig te maak nie. Trouens, sy dissipels moet selfs pro-aktief optree deur van hulle kant af die inisiatief te neem om versoening te bewerkstellig met diegene wat in 'n gebroke verhouding teenoor hulle staan. In Matteus 5:23-24 sê Jesus dat mens selfs jou belangrikste godsdienstige handelinge ter syde moet stel as dit jou byval dat jou broer iets teen jou het. Dit is bykans asof Jesus wil sê dat God bereid is om maar so 'n rukkie te wag sodat die burgers van sy koninkryk eers hulle aardse verhoudinge in orde kan kry. Immers, slegs binne 'n situasie waar Christengelowiges gesonde verhoudinge met andere handhaaf, kan hul verhouding met God gedy.

Wat weerwraak betref, het die Joodse leiers gedurende die eerste eeu op regsvlak hiervoor ruimte gelaat, soos wat die bekende aanhaling van Jesus in Matteus 5:38 duidelik maak: "'n Oog vir 'n oog en 'n tand vir 'n tand" (vgl ook Eks 21:24; Lev 24:20). Hiermee saam het hulle ook nog vir hulle volgelinge geleer dat hulle wel hulle naastes (dit wil sê, hulle Godvresende volksgenote) moes liefhê, maar dat hulle hul vyande kon haat (5:43). Teenoor dié vergeldingsdogma en "religieuse" optrede teenoor andere kom sê Jesus egter volgens Matteus dat sy volgelinge telkens die ander wang moet draai as hulle op die regterwang geslaan word. Indien hulle met ander woorde beledig of selfs fisies aangerand word, moet hulle die totaal onverwagte doen deur nie agressief te reageer nie. Deur juis nie die 
arena van geweld en weerwraak te betree nie, kon hulle bydra om die spiraal van konflik en haat onder mense teen te werk en vervul hulle ook hul Godgegewe taak as vredemakers (5:9).

Volgens Matteus sê Jesus ook dat as iemand een van sy volgelinge sou dwing om hulle goed 'n kilometer ver te dra, soos wat die Romeinse soldate dikwels van hul onderdane vereis het, hulle dit met blymoedigheid nog 'n kilometer verder moes dra (5:41). Trouens, Jesus verwag selfs dat sy navolgers liefde sal bewys aan hulle vyande (5:44). Uiteraard vra dit groot selfverloëning en opoffering, asook dat gelowiges ' $n$ interne heroriëntasie teenoor hulle medemense moet maak deur onder andere: (a) op te hou om wraakgedagtes teenoor hulle te koester; (b) te besef dat alle mense, hetsy vriend of vyand, die objekte van hulle liefde en diens is; (c) dat alle mense in God se oë die reg op die lewe het en (d) dat hulle nie deur enige vorm van geweld hierdie basiese reg ontneem mag word nie.

Volgens Matteus roep Jesus sy volgelinge in die bergrede ook op om volmaak te wees soos wat hulle Hemelse Vader volmaak is (5:48). Binne hierdie konteks dui dit nie soseer op etiese volmaaktheid nie, maar eerder op God se aard wat gelowiges daagliks moet naleef. Immers, omdat God volmaak is, het $\mathrm{Hy}$ al sy vyande lief, skenk Hy aan hulle gawes soos reën en lewenskrag en gee Hy selfs ook aan hulle die ewige lewe. Daarom moet Jesus se dissipels hierdie barmhartigheid konkreet naleef deur aan almal wat daagliks hulle lewenspaaie kruis, in woord en daad goed te doen.

Ook in die Lukasevangelie kom 'n aantal treffende voorbeelde van Jesus se voorskrifte ten opsigte van sy volgelinge se optrede teenoor andere voor, waaronder die gelykenis van die barmhartige Samaritaan (10:25-37) sekerlik die mees aangrypende is 10 . Die daadaspek van naasteliefde staan hier voorop as Jesus die voorbeeld van 'n Samaritaan gebruik wat uiteindelik aan die slagoffer van 'n aanranding op die gevaarlike pad tussen Jerusalem en Jerigo hulp verleen nadat die Joodse godsdienstige leiers by hom verbygestap het. Gegewe die haat wat daar tussen die Jode en die Samaritane bestaan het sedert die skeuring van die Noordryk en die Suidryk en die absolute veragting waarmee veral die Joodse godsdienstige leiers die Samaritane bejeën het sedert laasgenoemdes se plasing van doodsbeendere in die tempel rondom 6-9 $\mathrm{nC}$, is dit 'n besonder skerp gelykenis. Dit dien as ' $\mathrm{n}$ duidelike spieël vir wat Lukas met naasteliefde bedoel: naasteliefde strek verby menslike vooroordele en stereotipes. Dit is totaal blind vir die status, omstandighede, afkoms, geslag en gesindheid van andere en sien hulle as mense aan wie barmhartigheid bewys moet word. In dié verband moet veral die slagoffers van geweld die objekte van Christene se hulpverlening wees.

In die Markusevangelie is daar eweneens 'n sterk klem op konkrete dissipelskap ${ }^{11}$. In 9:33-38 en 10:35-45 sê Jesus byvoorbeeld dat die grootste persoon ir die koninkryk dié een is wat hom/haarself as die geringste ag en wat bereid is om 
andere te dien. Jesus se navolgers moet hiervolgens die fokus weg van hulleself na diegene rondom hulle verskuif. Vir Markus beteken dissipelskap dan om andere met woord en daad te dien. Dit vra selfverloëning, opoffering en lyding (8:34-38); selfs die bereidheid om jou lewe ter wille van Christus en andere op die spel te plaas.

\subsubsection{Jesus verwerp die gebruik van geweld ter bevordering van God se koninkryk}

Volgens die evangeliste het Jesus dit wat Hy aan sy volgelinge ten opsigte van hulle optrede teenoor andere geleer het, self in woord en daad uitgeleef. Hy het mense nooit tot geweldadige protes teen die heersende godsdienstige stelsel opgeroep nie ${ }^{12}$. Selfs die tempelreiniging teen die einde van sy openbare optrede (Mark 11), was geensins 'n voorbeeld van geweldadige optrede aan sy kant nie. Dit was eerder 'n simboliese daad (in dieselfde kategorie as die profetiese handelinge van OuTestamentiese figure soos Jeremia en Esegiël) waardeur Jesus op sigbare wyse die "heiligheidsideologie" van die Jode afgewys het en die negatiewe gevolge wat dit vir hulle inhou, aan die lig gebring het ${ }^{13}$.

Wat die Romeinse besetters betref, het Jesus, anders as die teokratiese bewegings van sy dag, mense eweneens ook nie tot geweldadige verset teen hulle aangehits nie. Volgens die evangelieskrywers het Hy Hom immers nie beywer om 'n aardse koninkryk daar te stel wat die politieke mag in die hande van die Jode sou plaas nie. Sy positiewe antwoord in Mark 12:13-17 toe die Joodse leiers Hom by geleentheid gevra het of die betaal van belasting aan die keiser in orde was, onderstreep genoemde feit. Sommige mense het egter verwag dat Jesus een of ander aardse koninkryk tydens sy optrede sou vestig soortgelyk aan die ou Dawidiese dinastie wat politieke bevryding vir die Jode sou meebring. As Jesus byvoorbeeld met sy laaste pelgrimstog naby Jerusalem kom, meen sommige van sy aanhangers dat Hy dan die koninkryk van God sigbaar gaan instel (Luk 19:11). En wanneer hy Jerusalem 'n rukkie later op die rug van 'n donkie binnery, vereer die skare Hom deur hulle klere en groen takke in die pad voor Hom te gooi en Hom te prys as die een wat Dawid se koninkryk kom vestig (Mark 11:1-11). Tog gee Jesus nooit toe aan sodanige konnotasies wat aan sy optrede gekoppel is nie.

In teenstelling met Jesus se geweldlose verkondiging van die koninkryk van God het die Joodse leiers op hulle beurt egter van fisiese geweld gebruik gemaak om Hom te elimineer deur Hom uiteindelik as 'n politieke misdadiger te laat knuisig. Wanneer ideologiese geweld in sy verskillende vorme (soos beledigings en etikettering) immers nie daarin slaag om verkondigers van teenoorstaande wêreldbeskouinge stil te maak nie, is fisiese geweld dikwels die laaste (deesdae selfs die eerste) opsie vir die aanhangers van bepaalde ideologieë. Dit verteenwoordig 
die sterkste en mees irrasionele vorm van protes teenoor enige teenoorstaande wêreldbeskouing. Maar selfs toe die godsdienstige owerhede Jesus laat arresteer het en Hy fisiek aangerand is, het Hy hom weerhou van enige vorm van weerwraak. Al die evangeliste berig trouens dat Jesus selfs een van sy volgelinge se aanvanklike pogings om sy arresteerders met die swaard te verdryf, van die hand gewys het (Mark 14:53-50 par). Tydens sy kruisiging het Hy tot op die laaste nog sy Vader se vergifnis oor sy teregstellers afgebid (Luk 23:34).

\section{Slot: Jesus se nuwe visie vir 'n geweldadige samelewing}

Die eerste eeuse Palestina was geensins 'n geordende, vredevolle samelewing nie. Te midde van die teenwoordigheid van die gehate Romeine, het die groep Jode wat tot die godsdienstige elite behoort het hulle sienings oor hoe God gedien moes word as normatief vir die res van die bevolking beskou en hulle gedistansieer van diegene wat dit nie uitgeleef het nie. Laasgenoemdes was die slagoffers van ideologiese geweld: hulle is as "sondaars", met wie alle kontak vermy moes word, gebrandmerk.

'n Aantal teokratiese bewegings wat God se beheer oor Palestina met geweld probeer vestig het, het rondom die eerste eeu op die been gekom. As gevolg van die uitsigloosheid wat vele Jode se bestaan gekenmerk het vanweë geweld, misdaad, verlies van hulle eerbare posisies en aardse goedere, het baie van hulle by dié tipe bewegings aangesluit in pogings om iets van hulle verlore eer te probeer herwin.

Binne hierdie geweldadige samelewing het Jesus rondom 28-30 nC opgetree. Volgens die sinoptiese evangelies het $\mathrm{Hy}$ 'n alternatiewe bestaanswyse verkondig wat lynreg teen die heersende sosiale opset van die Jode ingedruis het. In dié proses het Jesus vir sy navolgers 'n nuwe blik op God as 'n barmhartige Vader wat Hom oor sondaars ontferm, gebied. Hy het ook gesê dat geweld geen plek in sy navolgers se lewens het nie. Net soos God moes hulle onder alle omstandighede aan andere goed doen, wie of wat diesulkes ook al mag wees. Jesus het nie sy sienings met geweld probeer vestig nie. Hy wou die samelewing eerder verander deur mense se innerlike oriëntasie teenoor God en andere te wysig. Sy rewolusie was met ander woorde nie 'n rewolusie van die swaard nie, maar 'n rewolusie van die liefde. En hierdie rewolusie moet vandag nog steeds voortduur. Want nie net in die eerste eeu nie, maar ook in die Suid-Afrika van die 1990's bied dit die enigste weg tot ware vrede. Daarom moet navolgers van Jesus tot op hede steeds: (a) 'n nuwe ingesteldheid van liefde en barmhartigheid teenoor alle ander mense hê; (b) naasteliefde in konkrete dade aan andere bewys, veral aan die slagoffers van geweld; (c) andere se reg op die lewe te alle tye respekteer en help beskerm; (d) geweld aktief teenstaan deur die gevare van geweldadige ideologieë uit te wys en konfliksituasies te help ontlont; (e) die bevrydende evangelie van Christus wyd en 
syd verkondig, veral die norme wat hiervolgens geld ten opsigte van gelowiges se ingesteldheid en gedrag teenoor andere.

Die kerk hou dié sleutel ter oplossing van vele probleme in ons land. Indien gelowiges die vredeslig van die evangelie in hierdie tyd baie duidelik laat skyn, kan dit ongetwyfeld 'n nuwe visie vir ons geweldadige samelewing bied. Maar op die ou end hang dit egter van elke Christengelowige af of hy/sy bereid is om Christus in woord en daad op die pad van naasteliefde na te volg.

\section{NOTAS:}

$1 \quad$ Hierdie artikel is 'n verwerkte weergawe van 'n referaat wat by die Predikante Konferensie tydens die opening van die Teologiese Fakulteit van die Universiteit van Pretoria (Afd B) in Februarie 1993 gelewer is.

2 Die hieropvolgende konstruksie van die heersende sosiale opset in Palestina rondom die eerste eeu en die verskillende manifestasies van geweld hierbinne, word op 'n hoë vlak van abstraksie onderneem. Daar word met ander woorde op algemene kenmerke van hierdie samelewing in die breë gefokus en nie soseer op al die onderlinge verskille tusssen die legio gemeenskappe, groepe en faksies hierbinne nie. Vir verdere leeswerk in hierdie verband kan die werke geraadpleeg word van R A Horsley \& J S Hanson, Bandits, prophets and messiahs: Popular movements in the time of Jesus, 1985; S Freyne, Galilee, Jesus and the gospels: Literany approaches and historical investigations, Philadelphia 1988, en A J Saldarini, Pharisees, Scribes and Sadducees in Palestinian society, Wilmington 1988.

3 By geleentheid het Pilatus byvoorbeeld 'n klomp Galileërs laat doodmaak terwyl hulle offers in die tempel gebring het (Luk 13:1). En by 'n ander geleentheid het hy vaandels met afbeeldings van die keiser se kop daarop in Jerusalem laat aanbring.

Vergelyk R L Rohrbaugh, "The city in the Second Testament", Biblical Theology Bulletin 21 (1991), 67-74.

Vergelyk J H Neyrey, "The symbolic universe of Luke-Acts: They turn the world upside down", in The social world of Luke-Acts: Models for interpretation (Edited by J H Neyrey), Peabody 1991, 271-304.

Vergelyk J Jeremias, Jerusalem in the time of Jesus, London ${ }^{4} 1979,303-312$.

Vergelyk die besprekings van die heersende sosio-ekonomiese omstandighede in Judea en Galilea in Horsley \& Hanson, $a$ w, 1985, 48-76; H Moxnes, The economy of the kingdom: Social conflict and economic relations in Luke's gospel, Philadelphia 1988, 22-74, en W S Vorster, Jesus the Galilean: Eschatological prophet and/or wisdom teacher?, Pretoria 1990, 1-10.

8 Vergelyk die bespreking van Jesus se opvattinge oor die koninkryk van God in J Gnilka, Jesus von Nazaret: Botschaft und Geschichte, Freiburg 1990, 87. 
165; J D Crossan, The historical Jesus: The life of a Mediterranean Jewish peasant, San Francisco 1991, 345-351, en S J Joubert, "Meestersimbool van 'n nuwe werklikheid: Jesus van Nasaret en die koninkryk van God volgens die sinoptiese evangelies", In die Skriflig 27 (1993), 91-107.

9 Vergelyk die verskillende insiggewende besprekings van die bergrede in $\mathrm{G}$ Strecker, Die Bergpredikt: Ein exegetischer Kommentar, Göttingen 21985; G Dautzenberg, "Mt 5, 43c und die antike Tradition von der jüdischen Misanthropie", in Studien zum Matthäusevangelium (Festschrift für Wilhelm Pesch, Hrsg. L Schenke), Stuttgart 1988, 47-78, asook J G van der Watt, "Jesus se etiese leringe", in Jesus van Nasaret: Verkondiging in konteks (J G van der Watt \& S J Joubert), Universiteit van Pretoria 1992, 102-108.

10 Vergelyk in hierdie verband $\mathbf{E}$ H Scheffler, Naasteliefde in LukasHandelinge", in Geloof en opdrag: Perspektiewe op die etiek van die Nuwe Testament (reds: C Breytenbach \& B C Lategan), Scriptura S9a 1992, 56-73, asook E H Scheffler, Suffering in Luke's Gospel, Zürich 1993.

11 Vergelyk J C Breytenbach, "Dissipelskap volgens Markus: Om Jesus na te volg" in a w, (reds: C Breytenbach \& B C Lategan), Scriptura S9a 1992, 2436.

12 S P Kealy, Jesus and politics, Collegeville 1990, bied 'n goeie bespreking aan van die "politieke optrede" van Jesus binne die wêreld van sy dag.

13 Vergelyk M Borg, Jesus: A new vision, San Francisco 1987, 174-176. 